\title{
Online Alışverişte Dürtüsel Kullanım, Kaçırma Korkusu, İçtepisel Satın Alma, İnternet Kaynaklı Yorgunluk ve Kaygı Arasındaki İlişkilerin İncelenmesi (Investigation of the Relationships Between Compulsive Use, Fear of Missing Out, Impulse Buying, Fatigue due to Internet and Anxiety in Online Shopping)
}

\author{
Hande AYHAN GÖKCEK iD a Ahmet Esad YURTSEVER (D) b Engincan YILDIZ iD c \\ a İstanbul Gelişim Üniversitesi, Yönetim Bilişim Sistemleri Bölümü, İstanbul, Türkiye. hayhan@gelisim.edu.tr \\ b İstanbul Gelişim Üniversitesi, Yönetim Bilişim Sistemleri Bölümü, İstanbul, Türkiye. aeyurtsever@gelisim.edu.tr \\ c İstanbul Gelişim Üniversitesi, Halkla İlişkiler ve Reklamcılık Bölümü, İstanbul, , Türkiye. enyildiz@gelisim.edu.tr
}

\begin{tabular}{l} 
MAKALE BİLGİSİ \\
\hline Anahtar Kelimeler: \\
Tüketici Davranışları \\
Psikoloji \\
Dijital Pazarlama \\
Online Alışveriş \\
Yapısal Eşitlik Modellemesi \\
Gönderilme Tarihi 24 Şubat \\
2021 \\
Revizyon Tarihi 3 Temmuz \\
2021 \\
Kabul Tarihi 5 Ağustos 2021
\end{tabular}

ÖZET

Amaç - Araştırmanın amacı, günümüzde hayatın vazgeçilmez bir unsuru olan internetin dürtüsel kullanımı ve kaçırma korkusu gibi psikososyal refah önlemlerinin içtepisel satın almaya etkisi ve bunun da internet kullanımı kaynaklı yorgunluk ve kişisel kaygıya olan etkisini tespit etmektir.

Yöntem - Araştırmanın ana kütlesi Türkiye'nin herhangi bir ilinde yaşayan, 18 yaş ve üstü olan ve çevrimiçi alışveriş yapan tüketicilerden oluşmaktadır. Verilerin toplanması için anket tekniği kullanılmış ve anketler Google Forms üzerinden oluşturulmuştur. Kartopu örnekleme yöntemi kullanılmıştır. Ankette kullanılan 5 ölçek; "Dürtüsel Kullanım”, "Kaçırma Korkusu”, "İçtepisel Satın Alma", "İnternet Kaynaklı Yorgunluk" ve "Kaygı" dır. Araştırma verileri IBM SPSS 24 ve IBM AMOS 27 istatistik paket programları ile analiz edilmiştir. Hipotezlerin test edilmesinde yapısal eşitlik modellemesi kullanılmıştır. Öncesinde, demografik değişkenlerin frekans analizi, verilerin normal dağılıma uygunluğu, keşfedici ve doğrulayıcı faktör analizleri, güvenirlilik analizleri yapılmıştır.

Bulgular - Araştırma sonuçlarına göre, öncelikle değişkenlerin gözlem değerlerinin çarpıklık ve basıklık değerleri incelendiğinde -2 ve +2 arasında oldukları tespit edilmiş olup, normal dağıtım şartını sağladıkları görülmüştür. Yapılan keşfedici faktör analizi sonrasında internet kaynaklı yorgunluk değişkeninin bir sorusunun faktör yükü 0.50 altında olduğundan ve toplam açılanan varyansı düşürdüğünden dolayı analizden çıkarılarak doğrulayıcı faktör analizi yapılmıştır. Doğrulayıcı faktör analizinin uyum iyiliği değerlerinin geçerli olduğu tespit edilmiştir. Gerçekleştirilen yapısal eşitlik modellemesi sonucunda dört hipotez de kabul edilmiş olup sınanan tüm ilişkiler arasında anlamlı ve pozitif bir etkileşim olduğu saptanmıştır. Dürtüsel kullanım içtepisel satın almayı 0,479 oranında pozitif anlamlı olarak, kaçırma korkusu içtepisel satın almayı 0,250 oranında pozitif anlamlı olarak, içtepisel satın alma internet kullanımı kaynaklı yorgunluğu 0,395 oranında pozitif anlamlı olarak, içtepisel satın alma kaygıyı 0,323 oranında pozitif anlamlı olarak etkilemektedir.

Tartışma - Analizler sonucunda elde edilen verilerin büyük bir kısmının ilgili literatürü desteklediği gözlemlenmiştir. Bununla birlikte daha önce rastlanılmamış bu çalışmaya özgü bir takım bulgulara da ulaşılmıştır. Araştırmada yapılan analiz sonuçları doğrultusunda ise çeşitli öneriler geliştirilmiştir.

\begin{tabular}{l} 
ARTICLE INFO \\
\hline Keywords: \\
Consumer Behavior \\
Psychology \\
Digital Marketing \\
Online Shopping \\
Structural Equation Modeling
\end{tabular}

ABSTRACT

Received 24 February 2021

Revised 3 July 2021

Purpose - The aim of the research is to determine the effect of psychosocial welfare measures such as impulsive use of the internet, which is an indispensable element of life today, and the fear of missing out, on impulsive buying and its effect on fatigue and personal anxiety caused by internet use.

Design/methodology/approach - The main mass of the research consists of consumers who live in any province of Turkey, are 18 years of age and older, and shop online. Survey technique was used to collect data and surveys were created via Google Forms. Snowball sampling method was used. 5 scales used in the survey; They are "Impulsive Use", "Fear of Missing Out", "Impulsive Buying”, "Internet-Induced Fatigue" and "Anxiety". The research data were analyzed with IBM SPSS 24 and IBM AMOS 27 statistical package programs. Structural equation modeling was used to test the hypotheses. Previously, frequency analysis of demographic variables, compatibility of data to normal distribution, exploratory and confirmatory factor analysis, reliability analysis were performed.

Findings - According to the results of the research, when the observation values of the variables were examined, the skewness and kurtosis values of the variables were found to be between -2 and +2 , and it was seen that they met the normal distribution condition. After the exploratory factor analysis, the factor loading of a question of the "Fatigue due to Internet" variable was less than 0.50 and the total explained

Research Article

Önerilen Atıf/Suggested Citation

Ayhan Gökcek, H., Yurtsever, A.E., Yıldız, E. (2021). Online Alışverişte Dürtüsel Kullanım, Kaçırma Korkusu, İçtepisel Satın Alma, İnternet Kaynaklı Yorgunluk ve Kayg1 Arasındaki İlişkilerin İncelenmesi, İşletme Araştırmaları Dergisi, 13 (3), 1985-2002. 
variancewas low, this 1 question was removed and confirmatory factor analysis was performed. It was determined that the goodness of fit values of the confirmatory factor analysis were valid. As a result of the structural equation modeling, all four hypotheses were accepted and it was found that there was a significant and positive interaction between all tested relations. Impulsive use positively affects impulsive buying at a rate of 0.479 , fear of missing out positively affects impulsive buying at a rate of 0.250 , impulsive buying positively affects fatigue due to internet with a positive rate of 0.395 and impulsive buying anxiety positively with a rate of 0.323 .

Discussion - It has been observed that most of the data obtained as a result of the analysis support the relevant literature. However, some findings specific to this study, which had not been investigated before, were also reached. Various suggestions have been developed in line with the analysis results of the research.

\section{GíRiş}

Bireyler her geçen gün internet ortamlarında daha fazla vakit geçirerek ihtiyaçlarını bu mecralar aracılığıyla gidermektedir. Bireyler kimi zaman internet üzerinden alışveriş yapmakta, kimi zamanlarda ise sosyal medya ortamlarının diğer kişilerle etkileşim kurma özelliğinde faydalanarak ihtiyaçlarını giderebilmektedir.

Bireyler, sosyal ăg siteleri aracılığıyla paylaşılan içerikleri kaçırma korkusuyla devamlı olarak kontrol ihtiyacı hissedebilmekte; kaygı seviyelerini düşürdüğü ve olumsuz duygularını azalttığı düşüncesiyle ve ihtiyacı olmadığı halde online satın alma ihtiyacı hissedebilmekte; internet alışverişlerinden veya sosyal medya kullanımlarından kaygı duymalarına rağmen bu davranışlarına devam etme ihtiyacı duyabilmekte; tüm bunların sonucunda da internet kullanımı kaynaklı yorgunluk duyabilmektedir. Özellikle tüm bu boyutların hangi değişken etkileşiminin en fazla olduğunun tespit edilmesi çalışmanın önemine işaret etmektedir.

$\mathrm{Bu}$ araştırma, online tüketici davranışlarına geniş bir açıdan yaklaşarak psikoloji ile birleştirmektedir. Araştırmanın amacı, günlük hayatımızın her alanında kullandığımız internetin dürtüsel kullanımı ve kaçırma korkusunun içtepisel satın almaya etkisi ve bunun da internet kullanımı kaynaklı yorgunluk ve kişisel kaygıya olan etkisini tespit etmektir. Araştırmanın önemi, hem literatürü belirli yönden desteklemesi hem de hiç ölçülmemiş ilişkilerin tespit edilmesi ve literatürdeki bu boşluğu dolduracak olmasıdır.

Çalışma kapsamında, kontrol edilemeyen bir dürtüye yanıt olarak ortaya çıkan, elde etme arzusu, o hissi yaşamak için bir davranışta bulunmak olan (O'Guinn ve Faber,1989: 147) “Online Alışverişte Dürtüsel Kullanım"; başkalarının ödüllendirici deneyimler yaşıyor olabileceğine dair yaygın bir endişe olarak tanımlanan Przybylski vd., 2013: 1841) "Kaçırma Korkusu"; satın alım gerçekleştirilmeden önce belirli bir ürün, marka veya kategoriye ilişkin satın alma niyeti içermeyen anlık ve hızlı bir satın alma şeklinde tanımlanan (Beatty ve Ferrell, 1998: 170) "İçtepisel Satın Alma”; internet kullanıcılarının farklı çevrimiçi sosyal medya platformlarına katılımları ve etkileşimleri yoluyla çeşitli teknolojik, bilgilendirici ve iletişimsel aşırı yükler yaşadıktan sonra zihinsel yorgunluktan muzdarip olduğu bir durum olarak tanımlanan (Ravindran, vd., 2014) "İnternet Kaynaklı Yorgunluk" ve olası zor anlar veya tehditler konusunda endişe duyan, yaygın olarak endişeli bir zihin durumu olarak tanımlanan (Stein ve Sareen, 2015) "Kaygı" Arasındaki İlişkiler üzerine detaylı bir literatür taraması yapılmıştır.

Yapılan araştırmayla birlikte daha önce literatürde araştırma sorunu haline getirilmemiş olan internet kullanımı kaynaklık yorgunluk ve kaygıyı bağımlı değişkenler olarak kurgulayarak içtepisel satın almanın bağımsız değişken olarak etkisi incelenmiştir. Bu eksiklikten yola çıkılarak literatürdeki boşluğun doldurulması amaçlanmıştır. Tüm bunlara ek olarak içtepisel satın alma değişkeni, dürtüsel kullanım ve kaçırma korkusunun bağımlı değişkeni olarak modellenmiştir. Tüm bu durumlar çalışmanın önemine işaret etmekle birlikte literatürdeki boşluğu da doldurabilecek niteliktedir.

\section{KAVRAMSAL ÇERÇEVE ve LITERATÜR TARAMASI}

\subsection{Dürtüsel Kullanım}

Gün geçtikçe artan internet kullanımı beraberinde birçok sonucu ortaya çıkarmıştır. Özellikle bireyler internette daha fazla zaman geçirmekte bu durum ise interneti sürekli kullanma ihtiyacını ortaya çıkarmaktadır. $\mathrm{Bu}$ durum ise artık bireyler üzerinde zorunlu internet kullanma davranışına neden olabilmektedir. 
Özellikle kimi durumlarda insanlar bu davranışlarını sınırlandırmakta güçlük çekebilmektedir. Bu tür davranışlar normalliğin sınırlarının ötesine geçer ve kimi durumlarda tüketicinin onları akıl ve irade yoluyla kontrol etme yeteneğini de aşar (Hirschman, 1992:158). Zorunlu tüketimi, kontrol edilemeyen bir dürtüye yanıt olarak ortaya çıan, elde etme arzusu, o hissi yaşamak için bir davranışta bulunmak ve bireyin tekrar edecek şekilde bir davranış göstermesine neden olan faaliyet olarak tanımlanmaktadır (O'Guinn ve Faber,1989:147). Bu davranış şeklini benimseyen bireyler devamlı olarak ilgili faaliyetlerine devam etmektedir. Dittmar ve Drury'e göre (2000: 114), bu kişiler maddi mallar edinmenin başarıya, kimliğe ve mutluluğa giden ana yol olduğuna inanarak daha güçlü maddi değerlere sahip olmaktadırlar. Daha çok dürtüyle satın almakta ve daha çok pişman olmaktadırlar.

Ürün satın alma ile ilgili olarak bireyler kaygılarını ve olumsuz duygularını azalttığı düşüncesiyle hareket etmekte, ancak satın alma davranışı tamamlandıktan sonra, yenilenen değersizlik ile sonuçlanan suçluluk duygusunu deneyimlendiği bir kısır döngü oluşturmaktadır (Harnish \& Bridges, 2015: 10). Kişilerde oluşan bu bağımlılık ve zorlayıcılık durumu kişilerin hayatlarını olumsuz bir şekilde etkileyebilmektedir. İnternete bağımlı bir şekilde hayatlarını sürdüren bu kişiler davranışlarını ve satın alma dürtülerini kontrol etmede sorunlar yaşayabilmektedir.

Sosyal ağ siteleri özellikle gençler için ilgili çekici bir konumdadır ancak kullanıcıların ilgili siteleri çok fazla kullanması durumunda olumsuz psikolojik sonuçlara maruz kalabilecekleri tespit edilmiştir. Sosyal medyayı aracılı̆̆ıyla, gençler ait olma ihtiyaçlarını karşılayabilirler, ancak aynı zamanda ait olmadıklarını ve önemli paylaşılan deneyimleri kaçırdıklarını hissettiklerinde anksiyeteden muzdarip olma riski daha yüksektir (Oberst vd. ,2017:51-53). Bu doğrultuda ise tekrardan bir bağımlı olma ortaya çıkmakta ve zorlayıcı bir internet kullanımına neden olmaktadır.

Bağımlı olmanın neden olduğu zorlayıcılıkla internette vakit geçiren, ürün satın alan ve sosyal ağ sitelerindeki içerikleri kaçıracaklarını düşünen kişiler vakitlerinin büyük bir çoğunluğunu bu aktivitelere harcamaktadır. Dürtüsel kullanım davranışı, bireyin rutin işleri rasyonel olarak yönetemediği davranışsal tüketimleri kontrol etmedeki anormalliği ifade eder (Hirschman, 1992). Badgaiyan ve Verma (2015), durumsal faktörlerin etkisini değerlendirerek içtepisel satın alma üzerine yaptıkları çalışmada, dürtüsel kullanım ile içtepisel satın alma davranışı arasındaki ilişkiyi ölçmeye çalışmışlardır. Ayrıca, Brand, vd. (2016) yaptıkları çalışmadaki bulgular, düzensiz, kontrol edilemeyen İnternet kullanımının zihinsel ve fiziksel işlevleri ve kararları etkileyen olumsuz bilişsel durumlara yol aç九t̆̆ını göstermektedir. Bu çalışmalardan yola çıkılarak oluşturulan hipotez şu şekildedir:

H1 : Dürtüsel Kullanım, İçtepisel Satın Alma davranışını istatistiksel olarak anlamlı şekilde etkilemektedir.

\subsection{Kaçırma Korkusu}

İnsanlar fiziksel olarak birlikte olamadığında, sosyal medya ortamları, bireyler için sosyal sermayelerini bağlamanın ve sürdürmenin veya büyütmenin bir yolu olarak görülmektedir. İnsanların gözlemlemeyi veya katılmayı seçebilecekleri farklı iletişim biçimleri için bir platformdur (Hetz vd. 2015:262). Bu platformlar aracılığıyla kişiler online olarak diğer kişilerle iletişim halinde kalabilmekte, online topluluklara katılabilmekte ve paylaşım yapma imkanına sahip olabilmektedirler. Tüm bu durumlar incelendiğinde sürekli olarak diğer kişi ve içeriklerle bağlantı halinde kalmak isteyen bireyler bu davranışlarını devamlı bir şekilde sürdürmeye başladıklarında içerikleri veya diğer kişilerin paylaştıklarını kaçıracakları korkusunu hissedebilmektedir.

Sosyal ağlara bağımlı olma durumu ortaya çıtığında özellikle bireyler var olan gelişmelere, paylaşımlara ve merak ettiği birçok konuya karşı kaçırma korkusu düşüncesi geliştirerek sosyal medya bağımlılıklarını pekiştirebilmektedirler. Kaçırma korkusu, başkalarının ödüllendirici deneyimler yaşıyor olabileceğine dair yaygın bir endişe olarak tanımlanmakla birlikte FoMO (Kaçırma Korkusu-Fear of Missing Out), başkalarının yaptıklarına sürekli bağlı kalma arzusuyla karakterize edilmektedir (Przybylski vd., 2013: 1841).

Yüksek FoMO seviyesinin sosyal medya yorgunluğunu tetiklemesi muhtemel olduğu düşünülmektedir. Araştırmanın sonucu olarak, FoMO'nun sosyal medya yorgunluğuna neden olduğunu ve bu ilişkinin zaman içinde tutarlı olduğu varsayılmaktadır (Dhir vd., 2018: 144). Sosyal medya ortamları bağlantı sağlamak için kullanılan araçlardır ve katılım vaadi sağlar (Ellison vd., 2007: 1143-1145). Sürekli bağlantı halinde olmak isteyen bireyler yaşadıkları kaçırma korkusu nedeniyle devamlı olarak bir kontrol ihtiyacı hissetmektedir. 
Baker vd' e göre (2016: 277), sosyal medya katılımındaki artış, döngüsel bir olumsuz sonuç döngüsüne neden olabilir.

FoMO çalışmaları, yüksek düzeyde FoMO'nun olumsuz psikolojik ve fizyolojik sonuçları olduğunu açıça ortaya koymuştur (Dhir vd., 2018: 144). Bu olumsuz durumlar ise anksiyete ve depresyon gibi birçok olumsuz sonuca neden olabilmektedir. Özellikle diğer kişilerin paylaştıklarını kaçırma korkusu ve var olan gelişmelerden haberdar olamama korkusu kişilerde ilişkili olduğu birçok durumu kaçıracağı endişesi yaratabilmektedir. Sorunlu sosyal ağ siteleri kullanımına ek olarak, bazı araştırmalar, artan SNS kullanım sıklığının depresyon ve anksiyete şiddeti ile ilişkili olduğu bulunmuştur (Dempsey, 2019: 1). Yapılan çalışmalar, kaybetme korkusuyla karşı karşıya kalan kişilerin, başkalarıyla bağlantıll, ilgili ve samimi olmaya yönelik psikolojik taleplere kapılmalarının muhtemel olduğunu göstermektedir (Beyens, vd., 2016). Ayrıca nispeten yakın tarihli araştırmalar, farklı olumsuz psikolojik ve fizyolojik koşullarla bir şeyleri kaçırma korkusunu ilişkilendirmişlerdir (Riordan, vd., 2015). Örneğin, Aydın, vd., (2021), tüketicilerin içtepisel satın alma davranışının biyolojik ritim, dürtüsellik ve kaçırma korkusu ile ilişkisini inceledikleri çalışma, kompulsif tüketicilerin, önemli ölçüde daha yüksek düzeyde dürtüsellik, depresyon, kaygı ve fırsatı kaçırma korkusu olduğunu göstermiştir. Bu çalışmalardan yola çıkılarak oluşturulan hipotez şu şekildedir:

H2 : Kaçırma Korkusu, İçtepisel Satın Alma davranışını istatistiksel olarak anlamlı şekilde etkilemektedir.

\section{3. İçtepisel Satın Alma}

İçtepisel satın alma; satın alım gerçekleştirilmeden önce belirli bir ürün, marka veya kategoriye ilişkin satın alma niyeti içermeyen anlık ve hızlı bir satın alma şeklinde açıklanmaktadır (Beatty ve Ferrell, 1998: 170). Yine başka bir tanımda içtepisel satın alma; daha önce bilinçli olarak tanımlanan bir sorun olmadan yapılan bir satın alma işlemi veya mağazaya girmeden önce oluşturulan bir satın alma niyeti şeklinde özetlenmiştir (Engel ve Blackwell, 1982' den aktaran Crawford ve Melewar, 2003: 87). Clover'ın (1950) içtepisel satın almayla ilgili ön araştırma çalışmasından on yıl sonra, Stern (1962) dört farklı içtepisel satın alma türünü tanımlamıştır. Bunlar: saflık, hatırlatma, öneri ve planlanmış içtepisel satın alma şeklindedir.

(i) Saf içtepisel satın alma: Normal bir satın alma modelini bozan bir yenilikçi veya farlı satın alma şeklidir.

(ii) Hatırlatma içtepisel satın alma: Bir müşteri bir ürünü gördüğünde veya bir reklamı ya da ürünle ilgili diğer bilgileri hatırladığında ve evdeki stokun azaldığını veya bittiğini hatırladığında ortaya çıkan satın alma şeklidir.

(iii) Önerili içtepisel satın alma: Bir müşteri bir ürünü ilk kez gördüğünde ve ona olan ihtiyacı görselleştirdiğinde ortaya çıkar satın alma şeklidir.

(iv) Planlanmış içtepisel satın alma: Alı̧veriş yapan kişi, özel fiyat teklifleri, kupon teklifleri ve benzerleri temelinde belirli satın alma kararları verdiğinde gerçekleşen satın alma şeklidir.

Yapılan araştırmalar dürtü hissinin, tüketicilerin satın alma davranışı üzerinde ve süresince çok güçlü ve gerçek bir etki olduğunu vurgulamaktadır (Hausman, 2000). İçtepisel satın alma herhangi bir pazarlama alanıyla sınırlı olmamasına rağmen özellikle gıda alışverişlerinde sıklıkla karşımıza çıkmaktadır (Kollat ve Willett, 1967: 21). Rook (1987) yaptığı çalışmada içtepisel satın almanın özelliklerini şu şekilde tanımlamaktadır:

- Üründen gelen karşı konulmaz bir güç hissi,

- Ürünü hemen satın almak zorunda olma duygusu,

- Satın alma işleminden kaynaklanan olumsuz sonuçların görmezden gelinmesi,

- Heyecan duyguları, hatta coşku,

- Kontrol ve hoşgörü arasındaki çatışma. 
Hausman (2000), içtepisel satın almanın, ağırlıklı olarak Maslow'un "ihtiyaçlar hiyerarşisi" etrafında zayıf bir şekilde gruplanmış, daha lüks ihtiyaçlara uluşma arzusuyla güdülenmiş bir hedonik ihtiyaç olduğunu savunur. Bu hiyerarşide üst düzey ihtiyaçları karşılama çabaları, farklı dürtü satın alma davranışlarına yol açar. Bu durum, tüketicilerin eğlence, fantezi ve sosyal ya da duygusal tatmin gibi ekonomik olmayan nedenlerle satın almasına sebep olmaktadır. Önceki araştırmalar, içtepisel satın almanın kar maksimizasyonu varsayımlarını ihlal ettiği ve mantıksız olduğu sonucuna varmıştır. Denkleme hedonik bileşenler eklendikten sonra, içtepisel satın alma, yalnızca mal edinmenin bir aracı olmaktan çok değerli bir eğlence olarak görülebilir. İçtepisel satın alma yalnızca fiziki olarak mağazalara gidilerek yapılan alışverişlerde değil bununla birlikte internet üzerinden web siteleri aracılığıyla online yapılan alışverişlerde de görülmektedir. Yapılan bir çalışmada, özellikle internet üzerinden yapılan alışverişlerde fiziki olarak gidilip mağazalardan yapılan alışverişlere göre daha fazla içtepisel alışveriş olduğu tespit edilmiştir (Donthu ve Garcia, 1999: 56). Kazi, vd. (2019), ise sosyal medya ve internetin Pakistan'da içtepisel satın alma davranışı üzerindeki etkisi üzerine yaptıkları çalışmada ise, sosyal medyanın tüketicilerin içtepisel satın alma davranışları üzerinde olumlu ve önemli bir etkisi olduğunu tespit etmişlerdir. Bu çalışmalardan yola çıkılarak oluşturulan hipotez şu şekildedir:

H3 : İçtepisel Satın Alma, internetin alışveriş amaçlı kullanımı kaynaklı yorgunluğu istatistiksel olarak anlamlı şekilde etkilemektedir.

\section{4. İnternet Kaynaklı Yorgunluk}

İnternet ve sosyal medya günümüzde, eşler arasındaki, işletme ile tüketici ya da işletmeler arasındaki akla gelebilecek her türlü iletişimin doğasını değiştirmiştir. Nitekim her geçen gün internet kullanım oranları yükselmeye devam etmektedir. Yapılan çalışmalar internette geçirilen süre ve internette karşılaşılan içerik miktarının, internet kaynaklı yorgunluğu tetiklediğini göstermektedir (Bright, vd., 2015: 148). Önceki araştırmalar, internet kaynaklı yorgunluğu, internet kullanıcılarının farklı çevrimiçi sosyal medya platformlarına katılımları ve etkileşimleri yoluyla çeşitli teknolojik, bilgilendirici ve iletişimsel aşırı yükler yaşadıktan sonra zihinsel yorgunluktan muzdarip olduğu bir durum olarak tanımlamıştır (Ravindran, vd., 2014). Giderek artan sayıda internet kullanıcısı, internet kaynaklı yorgunluk yaşadığı için internet kullanımlarını azaltma yoluna gitmektedir (Guest Post, 2017). Bu bilgi yoğunluğunun ve internet kaynaklı yorgunluğun ortaya çıkmasının en büyük nedenlerinden biri kişilerin gündemdeki gelişmeleri kaçırma korkusu olarak karşımıza çıkmaktadır. Gündemdeki konularla ilgili gelişmeleri kaçırma korkusu, bireylerde sosyal medyada geri kaldığı hissini tetikleyerek normalin üstünde bir internet kullanımına yol açmakta ve bunun sonucunda internet kaynaklı yorgunluk yaşama durumu daha olası hale gelebilmektedir (Dhir, vd. 2018).

Büyüyerek hastalık noktasına gelen internet kaynaklı yorgunluk, kişinin çevrimiçi etkinliğini yönetme becerisinin gerilemesine, internet kullanımının kullanıcının düşünceleri ve davranışları üzerindeki dayanılmaz hâkimiyetine ve birisi çevrimdışıyken büyük sinirlilik, huzursuzluk ve yalnızlık duygularına yol açabilmektedir (Meerkerk, vd. 2009). Psikologlar ve araştırmacılar, her geçen gün artan internet kaynaklı yorgunluğun olumsuz etkilerine dikkat çekmişler ve aşırı internet kullanımının fiziksel ve psikolojik sorunlara yol açabileceğini vurgulamışlardır (Odacı ve Çelik, 2013). İnterneti öz saygılarını artırmak ve diğer insanlardan olumlu tepkiler almak için kullanan insanların olumsuz çevrimiçi geri bildirim almak, öz saygılarına zarar verebilmekte ve psikolojik açıdan sağlık sorunlarının oluşması konusunda risk oluşturabilmektedir (Holfeld ve Sukhawathanakul, 2017).

İnternet kaynaklı yorgunluk, farklı kaynaklardan meydana gelebilmektedir. Kişilerin diğer insanlarla olan etkileşimi, markalarla ve şirketlerle etkileşimi internet kaynaklı yorgunluğa sebep olabilmektedir (Bright, vd., 2015: 150). Araştırmacılar, internet kaynaklı yorgunluğun hem tüketiciler hem de işletmeler için önemli olumsuz etkileri olduğunu belirtmektedirler (Oghuma vd., 2016). Tüketici düzeyinde, internet kaynaklı yorgunluk, hem zihinsel hem de fizyolojik açıdan deformasyona neden olmakta ve bu nedenle, tüketicilerin sağlıksız davranışlar geliştirmesine sebep olmaktadır (Choi ve Lim, 2016). Benzer şekilde, internet kaynaklı yorgunluk işletmeler için zararlı olabilir çünkü yorgunluk, işletmeler için daha düşük kâr anlamına gelebilmekte ve hatta en kötü senaryo olarak pazardan çekilmeyle sonuçlanabilmektedir (Dhir, vd., 2018). 


\subsection{Kayg1}

Kaygı, olası zor anlar veya tehditler konusunda endişe duyan, yaygın olarak endişeli bir zihin durumu olarak tanımlanmaktadır (Stein ve Sareen, 2015). Geleneksel psikoloji literatürü, kaygılı kişilerin, tehlikeleri ve tehditleri yanlış yorumlanma, mantıksız karar verme ve sistematik olmayan detaylarda kaybolma gibi çoklu algılama ve değerlendirme bozukluklarından muzdarip olma ihtimalinin yüksek olduğunu ileri sürmektedir (Sokol, vd. 1989). Araştırmacılar, endişeli insanların kaygılı durumlarını sorunlu, kronik ve kaçınılmaz olarak görme eğiliminde olduklarını savunmaktadırlar (Dhir, vd., 2018). Dahası, bir işle meşgul olma ve konsantre olma durumunun zararlı olduğuna inanma eğilimindedirler (Madan, vd., 2014). Amerikan Psikiyatri Birliği'ne göre, kaygılı bir durum sırasında insanlar muhtemelen yorgunluk, bitkinlik ve fiziksel konularda şikâyet etmektedir (American Psychiatric Association, 2000).

Birçok farklı durum ve sebep kaygıya neden olabilmektedir. Bu nedenlerden başlıcaları ise şu şekilde sıralanabilir (Ejder, 2007; Sertbaş ve Bahar, 2004):

- Umutsuzluk,

- Güçsüzlük,

- Biyolojik, psikolojik ve çevresel faktörler,

- Biyolojik, psikolojik ve sosyal unsurlara karşı olan tehditler,

- Özgüvene karşı olan tehditler,

- Kişinin dayanma mekanizmasının/kaynaklarının efektif olarak kullanılamaması,

- Kişinin dayanma stratejilerinin tüketilmesi,

- Kişinin dayanma yeteneklerini aşan stres düzeyleri,

- Gerçekçi ya da ulaşılabilir olmayan ihtiyaçların/beklentilerin karşılanamaması,

- Uzun dönemli hastalığa karşı verilen cevap.

Son zamanlarda yapılan çalışmalar sosyal medya kullanıcıları arasında kaygının ne derece yaygın olduğunu tespit etmek için yoğunlaştırılmıştır. Yapılan çalışmalarda elde edilen verilere göre aşırı sosyal medya kullanımının, dikkat dağınıklığı ve psikolojik problemlerin yatıştırılması (Ha, vd., 2015; George, vd., 2013) ve zihinsel yorgunluk ve dikkat eksikliği ile bağlantılı olduğu tespit edilmiştir (Sriwilai ve Charoensukmongkol, 2016). Teknolojinin önemli ölçüde geliştiği günümüzde, internet, akıllı telefonlar, sosyal medya kullanımı hayatımızın değişmez parçalarından biri haline gelmiştir ve hatta internet bağımlılığı, cep telefonu bağımlılığı ve takıntılı şekilde akıllı telefon kullanımı konuları günümüzde araştırmacıların en çok yoğunlaştığı sorunlar haline gelmiştir (Wolniewicz, vd., 2018; Müller vd., 2016; Kuss ve Lopez-Fernandez, 2016). Yaygınlaşmış kaygıya atıfta bulunan modern bir fenomen olarak, kişinin kendisinin yokluğunda başkalarının güzel ve ödüllendirici deneyimler yaşayabileceğini hissetmesi yani kaybetme korkusu kaygı ile yakından ilişkili olduğunu göstermektedir. Kaygıya eğilimli insanların sosyal çevrelerinde olup bitenleri kaçırma endişeleri olduğunu varsaymak mantıklı olacaktır. Bu nedenle, sürekli kaygısı yüksek olan kişilerde, kaçırma korkusu daha yüksek olabilmektedir (Przybylski, vd., 2013). Diğer bir çalışmada kompulsif mobil cihaz kullanıcılarının, kompülsif olmayan kullanıcılara kıyasla kaygılı bir durumdan şikâyetçi olma ihtimalinin daha yüksek olduğu tespit edilmiştir (Lepp, vd., 2013). Primack vd. (2017), de yaptıkları çalışmada, kaygılı kullanıcıların olumsuz duygularını hafifletmek için farklı sosyal medya platformlarını kullanma olasılıklarının daha yüksek olduğunu gözlemlemişlerdir. Bilim insanları, kaygılı tüketicilerin yorgunluk ve bitkinlik gibi olumsuz sonuçlar yaşamaya meyilli olduklarını ve bu durumun satın almayla doğrudan ilişkili olduğunu iddia etmektedirler (Chaouali, 2016; Lorist, 2008). Bu nedenle, kaygı yaşayan tüketicilerin satın alım yaparken yanlış kararlar vermeleri muhtemeldir. Darrat, vd. (2016)' nin, tüketici kaygısı ve gerçeklerden kaçmanın merkezi rolü bağlamında, içtepisel satın almanın zorunlu satın almayı nasıl etkilediğini incelediği araştırmada, içtepisel satın almanın tüketicilerde kaygıyı artırdığını ve bunun da zorunlu satın almayla bağlantılı olduğunu tespit etmişlerdir. Diğer bir çalışmada Xiao, vd. (2020), COVID-19 salgını sırasında içtepisel satın alma üzerine çalışmış ve günlük aşırı bilgi yüklemesi ve günlük bilgi kaygısının, COVID-19 hakkında günlük olarak algılanan belirsizlik ile günlük içtepisel satın alma arasında tam bir zincirleme aracılık 
H. Ayhan Gökcek - A. E. Yurtsever - E. Y1ldız 13/3 (2021) 1985-2002

rolü oynadığını tespit etmiş ve kaygının içtepisel satın almaya büyük derecede etki ettiğini ortaya koymuştur. Bu çalışmalardan yola çıkılarak oluşturulan hipotez şu şekildedir:

H4 : İçtepisel Satın Alma, kaygıyı istatistiksel olarak anlamlı şekilde etkilemektedir.

\section{YÖNTEM}

\subsection{Evren ve Örneklem}

Araştırmanın ana kütlesi Türkiye'nin herhangi bir ilinde yaşayan, 18 yaş ve üstü olan ve çevrimiçi alışveriş yapan tüketicilerden oluşmaktadır. Pandemi nedeniyle Google Forms üzerinden online anket tekniği uygulanmış ve örnekleme yöntemi olarak kartopu örneklemesi tercih edilmiştir. Bu örnekleme yönteminin tercih edilme nedeni evren içindeki herhangi bir ya da birkaç kişi ile iletişim kurarak anketin dağıtılması ve o kişiler aracılığı ile zincirleme olarak diğer kişilere ulaşmanın hızıdır. Anket, sanal ortamda e-mail, Linkedin ve Whatsapp uygulaması ile dağıtılmıştır. Ankette e-ticaret sitelerinden alışveriş yapılıp yapılmadığı ile ilgili bir kontrol sorusu sorularak, cevap olarak "hayır" diyenler örneklemden çıkarılmıştır. Ankette, kullanılan 5 ölçek için toplam 24 adet, demografik değişkenler için 5 adet, online alışveriş yapılan platform ile ilgili bilginin alındığ 2 adet, toplamda 31 soru bulunmaktadır.

Araştırmada kullanılan dürtüsel kullanım, kaçırma korkusu, internet kaynaklı yorgunluk ve kaygı ölçekleri Dhir ve diğerlerinin 2018 yılında yayınlanan "Online social media fatigue and psychological wellbeing-A study of compulsive use, fear of missing out, fatigue, anxiety and depression" isimli makalesinden ve içtepisel satın alma ölçeği Rook ve Fisher'ın 1995 yılı “Normative influences on impulsive buying behavior" makalesi esas alınarak Türkçe'ye çevrilen Altıngül'ün 2015 yılı yayınından alınmıştır.

\subsection{Araştırma Modeli ve Hipotezler}

Araştırma modeli Şekil 1'de gösterilmektedir.

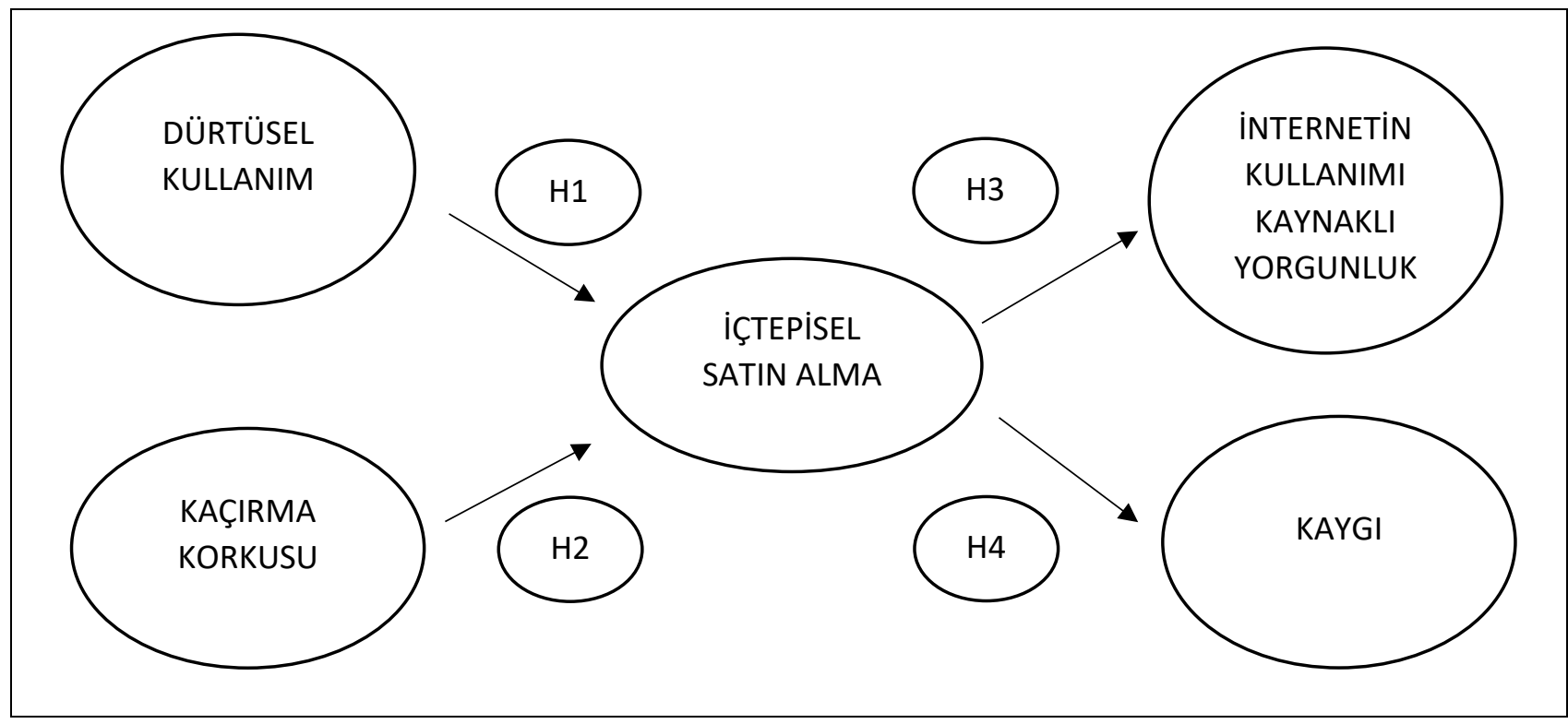

Şekil 1. Araştırma Modeli

Araştırmanın hipotezleri, literatür taramasından da açıklandığı ve dayanakları verildiği üzere Şekil 1’e göre aşağıdaki gibidir:

H1 : Dürtüsel Kullanım, İçtepisel Satın Alma davranışını istatistiksel olarak anlamlı şekilde etkilemektedir.

H2 : Kaçırma Korkusu, İçtepisel Satın Alma davranışını istatistiksel olarak anlamlı şekilde etkilemektedir.

H3 : İçtepisel Satın Alma, internetin alışveriş amaçlı kullanımı kaynaklı yorgunluğu istatistiksel olarak anlamlı şekilde etkilemektedir.

H4 : İçtepisel Satın Alma, kaygıyı istatistiksel olarak anlamlı şekilde etkilemektedir. 
H. Ayhan Gökcek - A. E. Yurtsever - E. Y1ldız 13/3 (2021) 1985-2002

\section{VERİLERİN ANALİİ, BULGULAR VE YORUM}

\subsection{Demografik Bulgular}

Tablo 1'de araştırmanın demografik değişkenlerine ilişkin frekans analizi yer almaktadır. Örneklem 390 kişiden oluşmaktadır $(\mathrm{N}=390)$. \%95 anlamlılık seviyesi hesaplanan örneklem sayısının 384 ve üstü kişiden toplanmasının analizler için yeterli olduğu daha önce yapılan çalışmalar sonucu tespit edilmiştir. (Barlett vd., 2001; Altunışık vd., 2010 ; Büyüköztürk vd., 2008;). Araştırmaya katılan 197 kişi ile kadınlar \%50,5 orana sahiptir. Ankete katılanların 207 kişisi \%53,1 oran ile bekâr, 172 kişisi evli olarak belirlenmiştir. Eğitim durumu en çok olan grup \%44,6 ile 174 kişi lisans mezunu olarak tespit edilmiştir. Bu grubu 76 kişi ile lise mezunları ve 72 kişi ile lisansüstü mezunları takip etmektedir. Araştırmaya katılanların 130 kişisi \%33,3 oranı ile 18-25 yaş aralığında, 126 kişi \%32,3 oranı ile 26-35 yaş aralığında ve 2 kişisi $\% 0,5$ oran ile 66 yaş ve üstüdür. Gelir durumuna bakıldığında, 111 kişi \%28,5 oranı ile 2.000 TL ve altı gelire sahipken 47 kişi \%12,1 oranla $6.501 \mathrm{TL}$ ve üstü gelire sahip olduğu tespit edilmiştir.

Tablo 1. Demografik Değişkenler Frekans Tablosu

\begin{tabular}{|c|c|c|c|}
\hline & & $\mathrm{N}$ & $\%$ \\
\hline \multirow[t]{2}{*}{ Cinsiyet } & Kadın & 197 & 50,5 \\
\hline & Erkek & 193 & 49,5 \\
\hline Toplam & & 390 & 100 \\
\hline \multirow[t]{3}{*}{ Medeni Durum } & Bekâr & 207 & 53,1 \\
\hline & Evli & 172 & 44,1 \\
\hline & Diğer & 11 & 2,8 \\
\hline Toplam & & 390 & 100 \\
\hline \multirow{6}{*}{ Eğitim Durumu } & İlkokul & 8 & 2,1 \\
\hline & Ortaokul & 6 & 1,5 \\
\hline & Lise & 76 & 19,5 \\
\hline & Ön lisans & 54 & 13,8 \\
\hline & Lisans & 174 & 44,6 \\
\hline & Lisansüstü & 72 & 18,5 \\
\hline Toplam & & 390 & 100 \\
\hline \multirow{6}{*}{ Yaş } & $18-25$ yaş & 130 & 33,3 \\
\hline & $26-35$ yaş & 126 & 32,3 \\
\hline & $36-45$ yaş & 67 & 17,2 \\
\hline & $46-55$ yaş & 51 & 13,1 \\
\hline & $56-65$ yaş & 14 & 3,6 \\
\hline & 66 yaş ve üstü & 2 & 0,5 \\
\hline Toplam & & 390 & 100 \\
\hline \multirow{5}{*}{ Gelir Durumu } & 2000 TL ve altı & 111 & 28,5 \\
\hline & $2301-3500 \mathrm{TL}$ & 68 & 17,4 \\
\hline & 3501-5000 TL & 77 & 19,7 \\
\hline & 5001-6500 TL & 87 & 22,3 \\
\hline & 6501 ve üstü & 47 & 12,1 \\
\hline Toplam & & 390 & 100 \\
\hline
\end{tabular}

\subsection{Normallik Dağılımı Testi}

Dürtüsel kullanım, kaçırma korkusu, içtepisel satın alma, internet kullanımı kaynaklı yorgunluk ve kaygı değişkenlerinin dağılımları incelenmiştir. Normal dağılım için gerekli koşul; değişkenlerin gözlem değerlerinin çarpıklık (skewness) ve basıklık (kurtosis) değerlerinin -2 ve +2 arasında olmasıdır(George ve Mallery.,2010). İncelenen değişkenlerin gözlem değerlerinin çarpıklık (skewness) ve basıklık (kurtosis) değerleri incelendiğinde -2 ve +2 arasında oldukları tespit edilmiş olup, normal dağılım şartını sağlamaktadır. 
H. Ayhan Gökcek - A. E. Yurtsever - E. Y1ldız 13/3 (2021) 1985-2002

AMOS istatistik programından alınan normallik dağılımına ait değişkenlerin çarpıklık (skewness) ve basıklık (kurtosis) değerleri Tablo 2'de verilmiştir.

Tablo 2. Normallik Dağılımı Skewness ve Kurtosis Değerleri

\begin{tabular}{|c|c|c|c|c|c|c|}
\hline Variable & $\min$ & $\max$ & skew & c.r. & kurtosis & c.r. \\
\hline ka5 & 1,000 & 5,000 & ,436 & 3,513 &,- 721 & $-2,906$ \\
\hline ka4 & 1,000 & 5,000 &,- 487 & $-3,924$ &,- 663 & $-2,671$ \\
\hline ka3 & 1,000 & 5,000 & ,464 & 3,737 &,- 594 & $-2,393$ \\
\hline ka2 & 1,000 & 5,000 & ,324 & 2,613 &,- 746 & $-3,006$ \\
\hline ka1 & 1,000 & 5,000 & ,058 & ,470 &,- 875 & $-3,526$ \\
\hline yo2 & 1,000 & 5,000 &,- 646 & $-5,211$ &,- 321 & $-1,294$ \\
\hline yo1 & 1,000 & 5,000 &,- 897 & $-7,232$ & ,392 & 1,578 \\
\hline its9 & 1,000 & 5,000 & ,409 & 3,301 &,- 827 & $-3,333$ \\
\hline its8 & 1,000 & 5,000 & ,475 & 3,830 &,- 459 & $-1,848$ \\
\hline its7 & 1,000 & 5,000 & 179 & 1,440 & $-1,168$ & $-4,710$ \\
\hline its6 & 1,000 & 5,000 & ,076 & 614 & $-1,239$ & $-4,996$ \\
\hline its5 & 1,000 & 5,000 & 1,075 & 8,664 & ,454 & 1,829 \\
\hline its4 & 1,000 & 5,000 & ,438 & 3,531 &,- 778 & $-3,138$ \\
\hline its3 & 1,000 & 5,000 & 1,006 & 8,109 & ,549 & 2,215 \\
\hline its2 & 1,000 & 5,000 & ,883 & 7,115 &,- 002 &,- 009 \\
\hline its1 & 1,000 & 5,000 & ,174 & 1,403 & $-1,219$ & $-4,914$ \\
\hline kk3 & 1,000 & 5,000 &,- 059 &,- 476 & $-1,068$ & $-4,306$ \\
\hline kk2 & 1,000 & 5,000 & ,419 & 3,376 &,- 780 & $-3,143$ \\
\hline kk1 & 1,000 & 5,000 & ,224 & 1,804 &,- 820 & $-3,307$ \\
\hline dk4 & 1,000 & 5,000 &,- 133 & $-1,076$ & $-1,050$ & $-4,233$ \\
\hline dk3 & 1,000 & 5,000 & ,068 & ,551 &,- 982 & $-3,957$ \\
\hline $\mathrm{dk} 2$ & 1,000 & 5,000 & ,010 & ,081 & $-1,000$ & $-4,032$ \\
\hline dk1 & 1,000 & 5,000 & 136 & 1,093 &,- 970 & $-3,911$ \\
\hline Multivariate & & & & & 88,205 & 25,683 \\
\hline
\end{tabular}


H. Ayhan Gökcek - A. E. Yurtsever - E. Y1ldız 13/3 (2021) 1985-2002

\subsection{Keşfedici ve Doğrulayıcı Faktör Analizleri ve Güvenirlik Analizi (Cronbach's Alpha)}

Değişkenlerin Keşfedici Faktör Analizine uygunluğunun incelenmesi sonucu ortaya çıkan KMO değerleri, Bartlett test anlamlılık değerleri ve toplam açıklanan varyans değerleri ise Tablo 3'de verilmiştir.

Tablo 3. KMO, Bartlett test anlamlılık ve toplam açıklanan varyans değerleri

\begin{tabular}{|lccc|}
\hline & KMO & Bartlett test sig & Toplam Açıklanan Varyans \\
Dürtüsel Kullanım & 0,754 & 0,000 & 60,979 \\
Kaçırma Korkusu & 0,627 & 0,000 & 72,600 \\
İçtepisel Satın Alma & 0,903 & 0,000 & 56,496 \\
İnternet Kullanımı Kaynaklı Yorgunluk & 0,500 & 0,000 & 72,683 \\
Kaygı & 0,779 & 0,000 & 61,155 \\
\hline
\end{tabular}

Tablo 4'de değişkenlerin keşfedici faktör analizi ve doğrulayıcı faktör analizi sonrası faktör yük dağılımları ve güvenirlik analizi sonuçları olan cronbach alpha değerleri gösterilmiştir. Dört boyutun güvenirliği 0,70 ve bir boyutun (Yorgunluk) güvenirliği 0,60 üstünde olduğundan ölçeklerin güvenilir olduğu sonucuna varılmıştır.

Bulunan sonuçlara göre, keşfedici faktör analizi sonrası bulunan sonuçlar, doğrulayıcı faktör analizi ile doğrulanmış, "yorgunluk" değişkenini oluşturan 3 sorudan biri olan YO3 ifadesi, faktör yükü 0,50 altında olduğundan ve toplam açıklanan varyansı çok düşürdüğünden (YO3 ifadesi dahil olan toplam açılanan varyans : 52,514) analizden çıkarılmıştır. Analizden çıkarılan sadece 1 ifade bulunmaktadır. Tüm ölçekler, tek boyut altında beklendiği gibi toplanmıştır.

Tablo 4. Keşfedici ve Doğrulayıcı Faktör Analizi Faktör Yükleri ve Boyut Güvenirlikleri

\begin{tabular}{|c|c|c|c|c|}
\hline & Değişken İsimleri ve İfadeler & $\begin{array}{l}\text { Faktör Yükü } \\
\text { (Keşfedici } \\
\text { Faktör } \\
\text { Analizi) }\end{array}$ & $\begin{array}{c}\text { Faktör Yükü } \\
\text { (Doğrulayıcı } \\
\text { Faktör } \\
\text { Analizi) }\end{array}$ & $\begin{array}{c}\text { Güvenirlilik } \\
\text { (Cronbach's } \\
\text { Alpha) }\end{array}$ \\
\hline \multirow[t]{4}{*}{$\begin{array}{l}\text { Dürtüsel } \\
\text { Kullanım }\end{array}$} & $\begin{array}{l}\text { DK1- İnterneti kullanmayı düşünerek ya da } \\
\text { internetin planlı kullanımı hakkında çok } \\
\text { zaman harcarım. }\end{array}$ & 0,660 & 0,528 & \multirow{4}{*}{0,784} \\
\hline & $\begin{array}{l}\text { DK2- İnterneti daha fazla kullanma dürtüsü } \\
\text { hissederim. }\end{array}$ & 0,831 & 0,734 & \\
\hline & $\begin{array}{l}\text { DK3- Kişisel sorunlarımı unutmak için } \\
\text { interneti kullanırım. }\end{array}$ & 0,819 & 0,778 & \\
\hline & $\begin{array}{l}\text { DK4- İnterneti kullanmam yasaklansa } \\
\text { huzursuz ya da rahatsiz hissederim. }\end{array}$ & 0,801 & 0,732 & \\
\hline \multirow[t]{3}{*}{$\begin{array}{l}\text { Kaçırma } \\
\text { Korkusu }\end{array}$} & $\begin{array}{l}\text { KK1 - Başkalarının benden daha kârlı } \\
\text { deneyimler yaşaması beni üzer. }\end{array}$ & 0,918 & 0,917 & \multirow{3}{*}{0,804} \\
\hline & $\begin{array}{l}\text { KK2 - Arkadaşlarımın benden daha kârlı } \\
\text { deneyimler yaşaması beni üzer. }\end{array}$ & 0,908 & 0,886 & \\
\hline & $\begin{array}{l}\text { KK3 - Arkadaşlarımın bensiz eğlendiğini } \\
\text { öğrendiğimde üzülürüm. }\end{array}$ & 0,715 & 0,529 & \\
\hline \multirow[t]{3}{*}{$\begin{array}{l}\text { İç Tepisel } \\
\text { Satın Alma }\end{array}$} & $\begin{array}{l}\text { İTS1 - İnternetten çoğu zaman spontane } \\
\text { (ani) bir şekilde alışveriş yaparım. }\end{array}$ & 0,728 & 0,716 & \multirow{3}{*}{0,902} \\
\hline & $\begin{array}{l}\text { İTS2 - “Düşünme al” benim alışveriş tarzımı } \\
\text { açılar. }\end{array}$ & 0,746 & 0,598 & \\
\hline & $\begin{array}{l}\text { İTS3 - İnternetten genellikle düşünmeden bir } \\
\text { şeyler alırım. }\end{array}$ & 0,804 & 0,686 & \\
\hline
\end{tabular}


H. Ayhan Gökcek - A. E. Yurtsever - E. Yıldız 13/3 (2021) 1985-2002

\begin{tabular}{|c|c|c|c|c|}
\hline & $\begin{array}{l}\text { İTS4 - İnternette "görürüm ve satın alırım" } \\
\text { ifadesi beni tanımlar. }\end{array}$ & 0,778 & 0,727 & \\
\hline & $\begin{array}{l}\text { İTS5 - "Önce al, sonra düşün” ifadesi benim } \\
\text { internetten alışveriş tarzımı tanımlar. }\end{array}$ & 0,727 & 0,603 & \\
\hline & $\begin{array}{l}\text { İTS6 - Bazen, internetten önceden } \\
\text { planlamadan alışveriş yaptığımı } \\
\text { hissediyorum. }\end{array}$ & 0,771 & 0,774 & \\
\hline & $\begin{array}{l}\text { İTS7 - } O \text { an nasıl hissediyorsam internetten o } \\
\text { hisse göre bir şeyler satın alırım. }\end{array}$ & 0,760 & 0,783 & \\
\hline & $\begin{array}{l}\text { İTS8 - İnternetten yaptığım alışverişlerin } \\
\text { çoğu plansızdır. }\end{array}$ & 0,774 & 0,719 & \\
\hline & $\begin{array}{l}\text { İTS9 - Bazen internetten aldıklarım } \\
\text { konusunda biraz düşüncesizim. }\end{array}$ & 0,671 & 0,647 & \\
\hline $\begin{array}{l}\text { İnternet } \\
\text { Kullanımı } \\
\text { Kaynaklı } \\
\text { Yorgunluk }\end{array}$ & $\begin{array}{l}\text { YO1 - İnternette arama yaptığımda } \\
\text { genellikle çok fazla bilgi alıyorum. }\end{array}$ & 0,858 & 0,778 & \multirow{3}{*}{0,64} \\
\hline & $\begin{array}{l}\text { YO2 - İnternette bulunan bilgi miktarı beni } \\
\text { sık sık şaşırtıyor. }\end{array}$ & 0,858 & 0,609 & \\
\hline & $\begin{array}{l}\text { YO3 - İnternette mevcut olan bilgi miktarı } \\
\text { beni geriyor ve bunaltıyor. }\end{array}$ & $\begin{array}{l}\text { Faktör Yükü } \\
\text { 0,50 altında } \\
\text { olduğundan } \\
\text { çıkarılmıştır. }\end{array}$ & & \\
\hline \multirow[t]{5}{*}{ Kayg1 } & $\begin{array}{l}\text { KA1 - Başkalarının benim hakkımda } \\
\text { söyledikleri konusunda endişelenirim. }\end{array}$ & 0,806 & 0,751 & \multirow{5}{*}{0,835} \\
\hline & $\begin{array}{l}\text { KA2 - Başkalarının beni sevmediği } \\
\text { konusunda endişelenirim. }\end{array}$ & 0,898 & 0,94 & \\
\hline & $\begin{array}{l}\text { KA3 - Başkaları beni sevmeyecek diye } \\
\text { korkarım. }\end{array}$ & 0,865 & 0,814 & \\
\hline & $\begin{array}{l}\text { KA4 - Başkalarının benim hakkımda ne } \\
\text { düşündüğ̈üü merak ederim. }\end{array}$ & 0,664 & 0,527 & \\
\hline & $\begin{array}{l}\text { KA5-Başkalarının benimle dalga geçtiğini } \\
\text { hissederim. }\end{array}$ & 0,642 & 0,486 & \\
\hline
\end{tabular}

Doğrulayıcı Faktör Analizinin AMOS istatistik programı görüntüsü Şekil 2'de gösterilmiştir.

Şekilde; DK= Dürtüsel Kullanım, KK= Kaçırma Korkusu, İTS= İç Tepisel Satın Alma, YO=İnternet Kullanımı Kaynaklı Yorgunluk ve KA= Kaygı değişkenlerini ifade etmektedir. 
H. Ayhan Gökcek - A. E. Yurtsever - E. Yıldız 13/3 (2021) 1985-2002

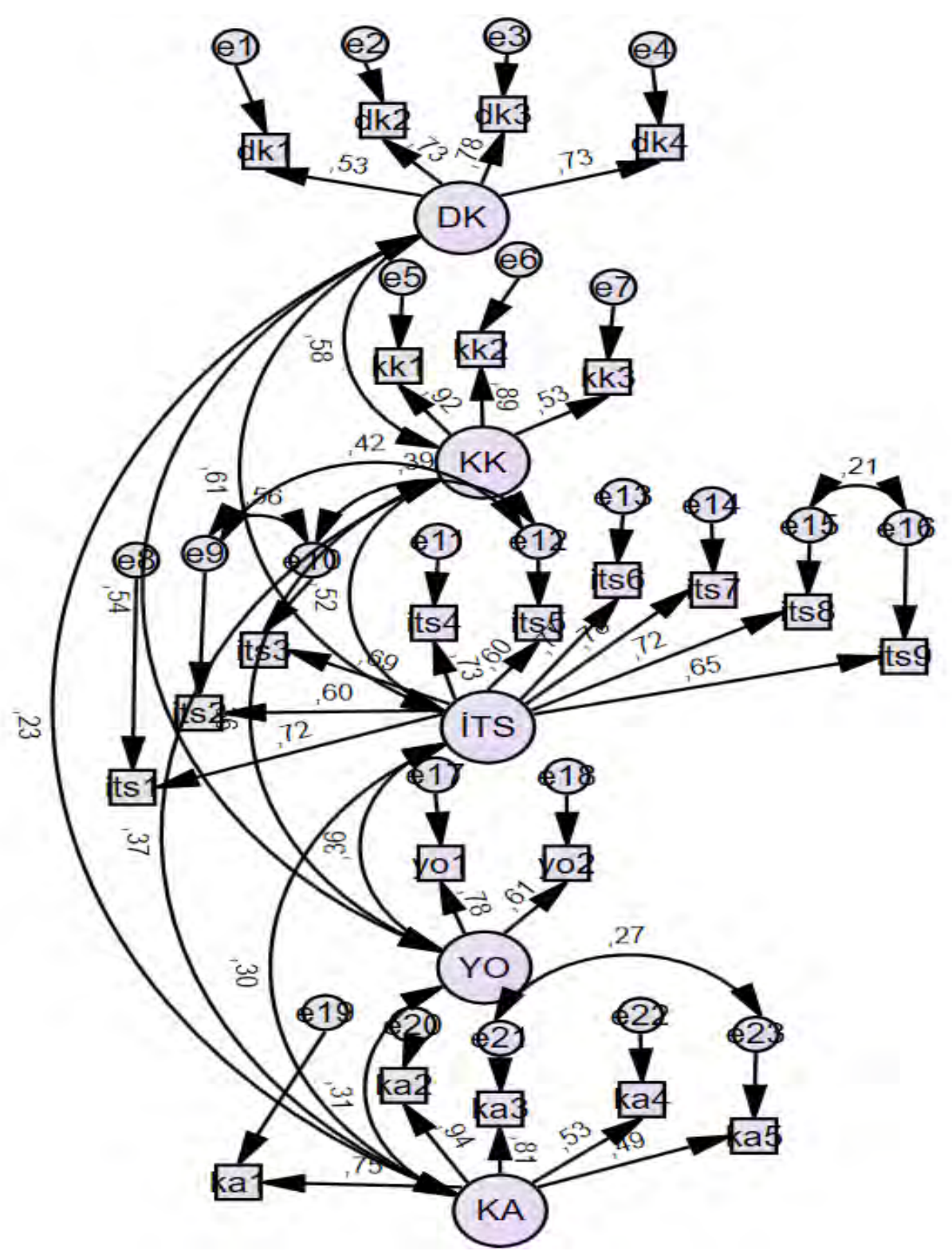

Şekil 2. Araştırma Modeli Doğrulayıcı Faktör Analizi

Doğrulayıcı faktör analizinin uyum iyiliği değerleri aşağıdaki Tablo 5'te yer almaktadır.

Tablo 5: Doğrulayıcı Faktör Analizi Uyum İndeks Değerleri

\begin{tabular}{|c|c|c|c|c|}
\hline $\begin{array}{l}\text { Uyum } \\
\text { İndeks }\end{array}$ & $\begin{array}{l}\text { Yapisal Eşitlik } \\
\text { Modeli }\end{array}$ & $\begin{array}{l}\text { Mükemmel Uyum } \\
\text { Kriterleri }\end{array}$ & $\begin{array}{l}\text { Kabul Edilebilir } \\
\text { Uyum Kriterleri }\end{array}$ & Değerlendirme \\
\hline$\chi^{2} /(\mathrm{df})$ & $\begin{array}{c}635,054 /(215)= \\
\mathbf{2 , 9 5 4}\end{array}$ & $0 \leq \chi^{2} / \mathrm{df} \leq 2$ & $2<\chi^{2} / \mathrm{df} \leq 5$ & $\begin{array}{c}\text { Kabul edilebilir } \\
\text { uyum }\end{array}$ \\
\hline RMSEA & 0.071 & $0 \leq \mathrm{RMSEA} \leq 0,05$ & $0,05<$ RMSEA $\leq 0,08$ & $\begin{array}{c}\text { Kabul edilebilir } \\
\text { uyum }\end{array}$ \\
\hline CFI & 0.907 & $0,95 \leq \mathrm{CFI} \leq 1,00$ & $0,90 \leq \mathrm{CFI}<0,95$ & $\begin{array}{c}\text { Kabul edilebilir } \\
\text { uyum }\end{array}$ \\
\hline NFI & 0.90 & $0,95 \leq \mathrm{NFI} \leq 1,00$ & $0,90 \leq \mathrm{NFI}<0,95$ & $\begin{array}{c}\text { Kabul edilebilir } \\
\text { uyum }\end{array}$ \\
\hline AGFI & 0,86 & $0,90 \leq \mathrm{AGFI} \leq 1,00$ & $0,85 \leq \mathrm{AGFI}<0,90$ & $\begin{array}{c}\text { Kabul edilebilir } \\
\text { uyum }\end{array}$ \\
\hline GFI & 0,90 & $0,95 \leq \mathrm{GFI} \leq 1,00$ & $0,90 \leq \mathrm{GFI}<0,95$ & $\begin{array}{c}\text { Kabul edilebilir } \\
\text { uyum }\end{array}$ \\
\hline
\end{tabular}




\section{H. Ayhan Gökcek - A. E. Yurtsever - E. Yıldız 13/3 (2021) 1985-2002}

Tablo 5'de doğrulayıcı faktör analizi sonucu ulaşılan uyum iyiliği değerlerine yer verilmiştir. Ölçüm modelinin $\chi^{2}$ değeri 635,054 olarak elde edilmiştir. $\chi^{2} / \mathrm{df}$ oranının 2,954 olması modelin kabul edilebilir uyum seviyesinde olduğunu göstermektedir. Ayrıca RMSEA, CFI, NFI, AGFI ve GFI değerlerinin kabul edilebilir uyum seviyesinde olduğu tespit edilmiştir. Buna bağlı olarak ölçülen modelin verilerinin, "iyi model uyum aralıkları" ile oldukça uyumlu olduğu görülmüştür. Bu veriler ölçüm modelinin genel uygunluğunun gayet iyi olduğunu göstermektedir (Munro, 2005; Schreiber, Nora, Stage, Barlow and King, 2006; Şimşek, 2007; Schumacker ve Lomax, 2010; Waltz, Strcikland ve Lenz 2010; Wang ve Wang, 2012 ; Çapık,2014:199).

\subsection{Yapısal Eşitlik Modellemesi ve Hipotezlerin Testi}

Tablo $6^{\prime}$ da doğrulayıcı faktör analizi sonrası yapılan yapısal eşitlik modellemesi ile ulaşılan uyum iyiliği değerleri gösterilmiştir. Ölçüm modelinin $\chi^{2}$ değeri 701,845 olarak elde edilmiştir. $\chi^{2} / \mathrm{df}$ oranının 3,190 olması modelin kabul edilebilir uyum seviyesinde olduğunu göstermektedir. Ayrıca RMSEA, CFI, NFI, AGFI ve GFI değerlerinin kabul edilebilir uyum seviyesinde olduğu tespit edilmiştir. Buna bağlı olarak ölçülen modelin verilerinin, "iyi model uyum aralıkları" ile oldukça uyumlu olduğu görülmüştür. Bu veriler yapısal modelin genel uygunluğunun gayet iyi olduğunu göstermektedir (Munro, 2005; Schreiber, Nora, Stage, Barlow ve King, 2006; Şimşek, 2007; Schumacker ve Lomax, 2010; Waltz, Strcikland ve Lenz 2010; Wang ve Wang, 2012; Çapık,2014:199).

Tablo 6: Yapısal Eşitlik Modeli Uyum İndeks Değerleri

\begin{tabular}{ccccc}
\hline $\begin{array}{c}\text { Uyum } \\
\text { Indeks }\end{array}$ & $\begin{array}{c}\text { Yapisal Eşitlik } \\
\text { Modeli }\end{array}$ & $\begin{array}{c}\text { Mükemmel Uyum } \\
\text { Kriterleri }\end{array}$ & $\begin{array}{c}\text { Kabul Edilebilir } \\
\text { Uyum Kriterleri }\end{array}$ & Değerlendirme \\
\hline \multirow{2}{*}{$2 /(\mathrm{df})$} & $\begin{array}{c}701,845 /(220)= \\
\mathbf{3 , 1 9 0}\end{array}$ & $0 \leq \chi^{2} / \mathrm{df} \leq 2$ & $2<\chi^{2} / \mathrm{df} \leq 5$ & Kabul edilebilir uyum \\
\hline RMSEA & $\mathbf{0 . 0 7 5}$ & $0 \leq \mathrm{RMSEA} \leq 0,05$ & $0,05<\mathrm{RMSEA} \leq 0,08$ & Kabul edilebilir uyum \\
\hline CFI & $\mathbf{0 . 9 0 2}$ & $0,95 \leq \mathrm{CFI} \leq 1,00$ & $0,90 \leq \mathrm{CFI}<0,95$ & Kabul edilebilir uyum \\
\hline NFI & $\mathbf{0 . 9 0 1}$ & $0,95 \leq \mathrm{NFI} \leq 1,00$ & $0,90 \leq \mathrm{NFI}<0,95$ & Kabul edilebilir uyum \\
\hline AGFI & $\mathbf{0 , 8 7}$ & $0,90 \leq \mathrm{AGFI} \leq 1,00$ & $0,85 \leq \mathrm{AGFI}<0,90$ & Kabul edilebilir uyum \\
\hline GFI & $\mathbf{0 , 9 0}$ & $0,95 \leq \mathrm{GFI} \leq 1,00$ & $0,90 \leq \mathrm{GFI}<0,95$ & Kabul edilebilir uyum \\
\hline
\end{tabular}

Şekil 3'te araştırmanın yapısal eşitlik modellemesinin AMOS istatistik programı görüntüsü verilmiştir. Yollar üzerindeki değerler, standart regresyon katsayılarını göstermektedir. Tablo 7'de bu katsayılar tablolaştırılmış ve anlamlılık değerleri gösterilmiştir.

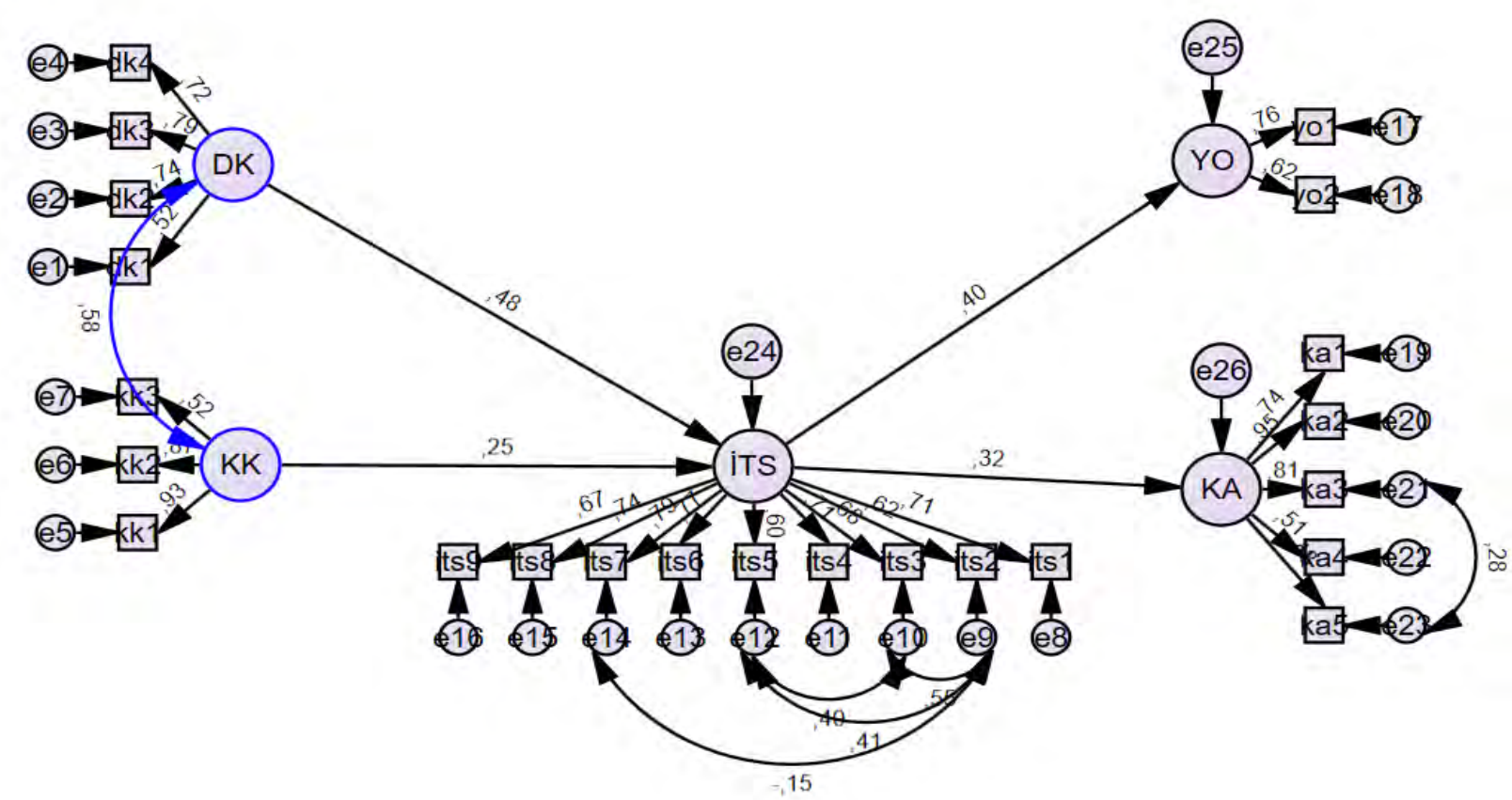

Şekil 3. Yapısal Eşitlik Modellemesi 
Tablo 7'de sınanan hipotezlerin standartlaştırılmış katsayıları ve anlamlılık değerleri gösterilmiştir. Yapısal eşitlik modellemesi sonuçlarına göre tüm katsayılar anlamlıdır $(p<0,05)$ ve araştırmanın dört hipotezi de kabul edilmiştir.

Analiz sonuçlarına göre; dürtüsel kullanım içtepisel satın almayı 0,479 oranında pozitif anlamlı olarak, kaçırma korkusu içtepisel satın almayı 0,250 oranında pozitif anlamlı olarak, içtepisel satın alma internet kullanımı kaynaklı yorgunluğu 0,395 oranında pozitif anlamlı olarak, içtepisel satın alma kaygıyı 0,323 oranında pozitif anlamlı olarak etkilemektedir. Sonuçlar, literatürü desteklemektedir. (Dhir, A., Yossatorn, Y., Kaur, P., \& Chen, S.,2018)

Dürtüsel kullanım, kaçırma korkusu ile karşılaştırıldığında içtepisel satın almayı yaklaşık 2 katı kadar fazla oranda etkilediği tespit edilmiştir. İçtepisel satın almanın ise internet kaynaklı yorgunluğu kaygıdan biraz daha fazla oranda etkilediği ama aralarında büyük bir fark olmadığı anlaşılmıştır.

Sentez bir yorum yapılacak olursa, sınanan tüm ilişkiler arasında anlamlı ve pozitif bir ilişki bulunmakta, dürtüsel kullanımın içtepisel satın almayı en fazla etkilediği, içtepisel satın almanın ise kaygıyı en az oranda etkilediği tespit edilmiştir.

Tablo 7: Yapısal Eşitlik Modeli Standart Regresyon Katsayıları ve Anlamlılık Değerleri

\begin{tabular}{|c|c|c|c|c|c|c|}
\hline & & & $\begin{array}{c}\text { Standart Regresyon } \\
\text { Katsayı } \\
\text { Tahminleri }\end{array}$ & S.E. & C.R. & $\mathbf{P}$ \\
\hline İTS & $<--$ & $\mathrm{DK}$ &, 479 & , 122 & 5,953 & $* * *$ \\
\hline İTS & $<<--$ & KK & ,250 & ,053 & 4,007 & $* * *$ \\
\hline $\mathrm{YO}$ & $<---$ & İTS & ,395 & , 056 & 5,645 & $* * *$ \\
\hline KA & $<---$ & İTS & ,323 & 055, & 5,608 & $* * *$ \\
\hline
\end{tabular}

\section{SONUÇ VE TARTIŞMA}

İnternet, dünya genelindeki kullanıcılar arasında popüler bir bilgilendirme, iletişim ve alışveriş platformudur. Bunun bir sonucu olarak internet, hayatın çeşitli alanlarında kullanıcılara faydalı olmakla birlikte kullanımından kaynaklı olumsuz sonuçlar da kaçınılmazdır. İnternet kullanımı kaynaklı yorgunluk, kullanıcıların zihinsel ve davranışsal koşullarını olumsuz yönde etkileyen yaygın bir faktördür (Dhir, vd. 2018).

İnsanlar, internetin artık çok daha kolay erişilebilir, pratik ve güvenilir olmasından dolayı birçok işini çevrimiçi şekilde internet üzerinden halletmektedirler. Bireylerin ruh hali veya duygusal durumu, dürtüsel kişilik özellikleri ve demografik faktörler dahil olmak üzere internetten alışverişte dürtüsel çevrimiçi satın almayı etkileyen birçok faktör vardır (Chan vd., 2017). Ayrıca bazı ürün türleri de dürtüsel çevrimiçi satın almayı teşvik edebilmektedir. Hedonik değer sağlayan ürünler zevk duygularını (örneğin; eğlence ve heyecan) teşvik ederken, faydacı ürünler öncelikle işlevsel bir amaca hizmet ederler (Liang, 2017). Araştırmalar son zamanlarda internet kullanıcılarının kaçırma korkusuyla ile ilgili yaşadığı olumsuz sonuçları araştırmaya başlamışlardır (Beyens vd., 2016) ve bu durumun içtepisel satın alma ve internet kaynaklı yorgunluğa sebep olduğunu gösteren bulgular elde etmişlerdir (Dhir, vd. 2018; Hausman, 2000).

Bu çalışma, tüketici davranışı ve psikolojisi üzerine odaklanarak değişkenler arasındaki ilişkiyi büyük bir perspektiften yapısal eşitlik modellemesi ile araştırmıştır. Daha önceki bulunan araştırma sonuçları desteklenmekle birlikte, ilave olarak yeni ilişkilerin varlığ 1 tespit edilmiştir. Bu doğrultuda, Dhir, vd.ve Rook'un (Dhir, vd., 2018; Rook, 1987) geliştirdiği ölçeklerden yararlanılarak farklı boyutlar arasındaki ilişkilerin tespiti sağlanmıştır.

$\mathrm{Bu}$ araştırma, internet kullanımı kaynaklık yorgunluk ve kaygıyı bağımlı değişkenler olarak kurgulayarak daha önce rastlanılmayan içtepisel satın almanın bağımsız değişken olarak etkisini incelemiştir. Ayrıca, içtepisel satın alma değişkeni, dürtüsel kullanım ve kaçırma korkusunun bağımlı değişkeni olarak modellenmiştir. Sonuçlar, dürtüsel kullanımın içtepisel satın almayı, kaçırma korkusundan yaklaşık 2 katı kadar fazla anlamlı olarak pozitif etkilediğini fakat kaçırma korkusunun etkisinin de yadsınamaz derecede fazla olduğunu göstermektedir. Sonuçlar ayrıca, online alışverişlerde içtepisel satın almanın, internet kaynaklı 
yorgunluğu ve kaygıyı anlamlı ve pozitif etkilediğini göstermektedir. İnternet kullanımı kaynaklı yorgunluk ve kaygının bağımlı değişken olarak ele alındığı içtepisel satın almanın bağımsız değişken olarak etkisinin incelendiği bu araştırmayla birlikte "Dürtüsel Kullanım, Kaçırma Korkusu, İçtepisel Satın Alma, İnternet Kaynaklı Yorgunluk ve Kaygı" arasındaki ilişkiler çalışmanın konusunu oluşturmuştur. Araştırma sonuçları dahilinde, içtepisel satın almanın birçok boyuttan etkilediği ortaya koyulmakla birlikte dürtüsel kullanımın içtepisel satın alma üzerinde önemli bir etkisi olduğu sonucuna ulaşılmıştır. İçtepisel satın almanın hem bağımlı hem de bağımsız değişken olarak ele alınarak çalışmanın merkezine koyulması araştırmanın özgünlüğünü ortaya koymaktadır.

$\mathrm{Bu}$ araştırma, online içtepisel satın almayı merkeze koyarak hem kendisine etkilerini içeren hem de kendisinin etkilediği psikolojik kavramlarla daha derin ve kapsamlı bir anlayış oluşturmuştur. Tüketici davranışları ve psikolojine yönelik literatüre destek vermesi hedeflenmektedir.

Literatürde de yer aldığı üzere, yapılan araştırmalarda insanların yaptığı satın almaların birçok durumdan etkilenebildiği görülmektedir (Dittmar ve Drury, 2000: 114; Harnish \& Bridges, 2015: 10; Beatty ve Ferrell, 1998: 170). Kaçırma korkusunun insanlarda satın alma davranışına neden olduğu, depresif durumların satın alma üzerindeki etkisinin varlığı, içtepisel bir satın alma durumunun oluştuğu ve dürtüsel satın almanın insanlar üzerindeki olumlu veya olumsuz etkileri gibi birçok araştırma yapılmıştır. Bu araştırmalar ilgili literatürde verilmiştir. Bizlerin yapmış olduğu çalışma da tüm bu değişkenler arasındaki ilişkiler bütüncül bir şekilde ele alınarak önemli araştırma sonuçlarına ulaşılmıştır. Bu doğrultuda yapılan diğer araştırma bulguları ile karşılaştıııldığında (Dhir, vd., 2018; Rook, 1987) internet kullanımı kaynaklık yorgunluk ve kaygı bağımlı değişkenler olarak belirlenmiş ve içtepisel satın almanın bağımsız değişken olarak etkisini incelemiştir.

Bulgular sadece teori için değil, aynı zamanda içtepisel satın almadan kaynaklı potansiyel zararlı olasılıkların ele alınması açısından da faydalıdır. Aynı zamanda internet kullanımı kaynaklı yorgunluk ve kaygıyı daha fazla incelemek için gelecekteki araştırmaların yolunu açacaktır.

Araştırmanın sınırlılıkları ve gelecekteki çalışmalara öneriler:

Araştırmanın örneklemini Türkiye'de yaşayan, 18 yaş ve üzeri çevrimiçi alışveriş yapan tüketicilerden seçilen katılımcılar oluşturmuştur. Pandemi şartları sebebiyle insanların çevrimiçi alışverişe normalden daha fazla ilgi göstermesi bu örneklem seçiminde etkili olmuştur. Mekan ve zaman kısıdı sebebiyle 390 kişiye ulaşılabilmiştir. Gelecekteki çalışmalar için öneriler ise şu şekildedir:

Sosyal medyadan alışveriş yapan tüketiciler ile online alışveriş sitelerinden alışveriş yapan tüketiciler arasında, bu değişkenler açısından etkileşim farklılıklarının belirlenmesi

Demografik değişkenler açısından konular ele alınarak t-test ve ANOVA ile test edilerek farklılıklar varsa belirlenmesi,

Depresyon değişkeninin modele eklenerek, içtepisel satın almanın kaygıya olan etkisi ile karşılaştırma yapılması şeklinde sıralanabilir.

\section{KAYNAKÇA}

Altıngül, M. (2015). Özel alı̧̧eriş sitelerine yönelik algıllanan hizmet kalitesinin bilişsel çelişki, iç tepkisel satın alma ve yeniden satın alma niyeti üzerindeki etkisi. Yüksek Lisans Tezi, İstanbul Üniversitesi İşletme Anabilim Dalı, İstanbul.

Altunışık, R., Coşkun, R., Bayraktaroğlu, S. ve Yıldırım, E. (2010). Sosyal bilimlerde araştırma yöntemleri (SPSS uygulamalı). Ankara, TR: Pegem Akademi.

American Psychiatric Association (2000). Diagnostic and statistical manual of mental disorders (4th ed.). Washington, D.C: American Psychiatric Association, e-Course Syllabus, Amberton University.

Aydın, D., Selvi, Y., Kandeğer, A. ve Boysan, M. (2021). The relationship of consumers' compulsive buying behavior with biological rhythm, impulsivity, and fear of missing out, Biological Rhythm Research, Vol. 52, No. 10, 1514-1522.

Badgaiyan, A. J. ve Verma, A. (2015). Does urge to buy impulsively differ from impulsive buying behaviour? Assessing the impact of situational factors, Journal of Retailing and Consumer Services, 22, 145-157. 
Baker, Z. G., Krieger, H., \& LeRoy, A. S. (2016). Fear of missing out: Relationships with depression, mindfulness, and physical symptoms. Translational Issues in Psychological Science, 2, 275-282.

Barlett, J. E., Kotrlik, J. W. ve Higgins, C. C. (2001). Organizational research: Determining appropriate sample size in survey research. Information Technology, Learning, and Performance Journal, 19(1), 43-50.

Beatty, S. E. ve Ferrell M. E. (1998). Impulse buying: Modeling its precursors. Journal of Retailing, Vol.74, No.2, pp. 169-191.

Beyens, I., Frison, E., ve Eggermont, S. (2016). I don't want to miss a thing: Adolescents' fear of missing out and its relationship to adolescents' social needs, Facebook use, and Facebook related stress. Computers in Human Behavior, Vol. 64, pp. 1-8.

Brand, M., Young, K., Laier, C., Wölfling, K., \& Potenza, M. (2016). Integrating psychological and neurobiological considerations regarding the development and maintenance of specific Internet-use disorders: An interaction of person-affect-cognitionexecution (I-PACE) model. Neuroscience and Biobehavioral Reviews, Vol. 71, pp. 252-266.

Bright, L. F., Kleiser, S. B. ve Grau, S. L. (2015). Too much Facebook? An exploratory examination of social media fatigue. Computers in Human Behavior, Vol. 44, pp. 148-155.

Büyüköztürk, Ş., Kılıç Çakmak, E., Akgün, Ö. E., Karadeniz, Ş. ve Demirel, F. (2008). Bilimsel araştırma yöntemleri. Ankara, TR: Pegem Akademi Yayıncıllk.

Chan, T. K., Cheung, C. M. ve Lee, Z. W. (2017). The state of online impulse-buying research: A literature analysis. Information \& Management, Vol. 54 No. 2, pp. 204-217.

Chaouali, W. (2016). Once a user, always a user: Enablers and inhibitors of continuance intention of mobile social networking sites. Telematics Information, Vol. 33(4), pp. 1022-1033.

Choi, S. B. ve Lim, M. S. (2016). Effects of social and technology overload on psychological well-being in young South Korean adults: The mediatory role of social network service addiction. Computers in Human Behavior, Vol. 61, pp. 245-254.

Clover, V. T. (1950). Relative importance of impulse buying in retail stores. Journal of Marketing, Vol. 25, pp. 66-70.

Crawford, G. ve Melewar, T. C. (2003). The importance of impulse purchasing behaviour in the international airport environment. Journal of Consumer Behaviour, Vol. 3, No. 1, pp. 85-98.

Çapık, C. (2014). Geçerlik Ve Güvenirlik Çalışmalarında Doğrulayıcı Faktör Analizinin Kullanımı. Anadolu Hemşirelik ve Sağlık Bilimleri Dergisi, 17(3).

Darrat, A. A., Darrat, M. A. \& Amyx, D. (2016). How impulse buying influences compulsive buying: The central role of consumer anxiety and escapism, Journal of Retailing and Consumer Services, Vol. 31, Pages 103-108.

Dempsey, A. E., O'Brien, K. D., Tiamiyu, M. F., \& Elhai, J. D. (2019). Fear of missing out (FoMO) and rumination mediate relations between social anxiety and problematic Facebook use. Addictive Behaviors Reports , 9,100150 .

Dhir, A., Yossatorn, Y., Kaur, P. ve Chen, S. (2018). Online social media fatigue and psychological wellbeingA study of compulsive use, fear of missing out, fatigue, anxiety and depression. International Journal of Information Management, Vol. 40, pp. 141-152.

Dittmar, H., \& Drury, J. (2000). Self-image-Is it in the bag? A qualitative comparison between "ordinary" and "excessive" consumers. Journal of Economic Psychology, 21, 106-145.

Donthu, N. ve Garcia A. (1999). The internet shopper. Journal of Advertising Research, Vol. 39, pp. 52-58.

Ejder, S. (2007). Amniyosentez uygulanan gebelerin anksiyete düzeylerinin incelenmesi. Yüksek Lisans Tezi. Ege Üniversitesi Sağlık Bilimleri Enstitüsü. İzmir.

Ellison, N. B., Steinfield, C., \& Lampe, C. (2007). The benefits of Facebook "friends": Social capital and college students' use of online social network sites. Journal of Computer-Mediated Communication, 12, 11431168. 
George, D. R., Dellasega, C., Whitehead, M. M. ve Bordon, A. (2013). Facebook-based stress management resources for first-year medical students: A multi-method evaluation. Computers in Human Behavior, Vol. 29(3), pp. 559-562.

George, D., \& Mallery, P. (2010). SPSS for Windows step by step. A simple study guide and reference (10. Baskı). GEN, Boston, MA: Pearson Education, Inc.

Guest Post (2017). Facebook is facing user fatigue, Hyperbot. http://www. hypebot.com/hypebot/2017/02/facebook-facing-user-fatigue.html, Erişim Tarihi: 02.02.2021.

Ha, Y. W., Kim, J., Libaque-Saenz, C. F., Chang, Y. ve Park, M. C. (2015). Use and gratifications of mobile SNSs: Facebook and KakaoTalk in Korea. Telematics Information, Vol. 32, pp. 425-438.

Harnish, R. J., \& Bridges, K. R. (2015). Compulsive buying: The role of irrational beliefs, materialism, and narcissism. Journal of Rational-Emotive \& Cognitive-Behavior Therapy, 33(1), 1-16.

Hausman, A. (2000). A multi-method investigation of consumer motivations in impulse buying behaviour. Journal of Consumer Marketing, 17(5), pp. 403-419.

Hetz, P. R., Dawson, C. L., \& Cullen, T. A. (2015). Social Media Use and the Fear of Missing Out (FoMO) While Studying Abroad. Journal of Research on Technology in Education, 47(4), 259-272.

Hirschman, E. C. (1992). The consciousness of addiction: toward a general theory of compulsive consumption. Journal of Consumer Research, 19(2), 155-179.

Holfeld, B. ve Sukhawathanakul, P. (2017). Associations between internet attachment, cyber victimization, and internalizing symptoms among adolescents. Cyberpsychology, Behavior, and Social Networking, Vol. 20(2), pp. 91-96.

Kazi, A. G., Khokhar, A. A., Qureshi, P. A. B. ve Murtaza, F. (2019). The impact of social media on impulse buying behaviour in Hyderabad Sindh Pakistan, International Journal of Entrepreneurial Research, 2(2); 812.

Kollat, D. T. ve Willett R. P. (1967). Customer impulse purchasing behavior. Journal of Marketing Research, Vol. 4, No. 1, pp. 21-31.

Kuss, D. J. ve Lopez-Fernandez, O. (2016). Internet addiction and problematic internet use: A systematic review of clinical research. World Journal of Psychiatry, Vol. 6(1), pp. 143-176.

Lepp, A., Barkley, J. E. ve Karpinski, A. C. (2013). The relationship between cell phone use, academic performance: Anxiety and satisfaction with life in college students. Computers in Human Behavior, Vol. 31, pp. 343-350.

Liang, A. R. D. (2017). Considering the role of agritourism co-creation from a service-dominant logic perspective. Tourism Management, Vol. 61, pp. 354-367.

Lorist, M. M. (2008). Impact of top-down control during mental fatigue. Brain Research, Vol. 1232, pp. 113-123.

Madan, A., Mrug, S. ve Wright, R. A. (2014). The effects of media violence on anxiety in late adolescence. Journal of Youth and Adolescence, Vol. 43, pp. 116-126.

Meerkerk, G.-J., Van Den Eijnden, R. J. J. M., Vermulst, A. A., ve Garretsen, H. F. L. (2009). The Compulsive Internet use scale (CIUS): Some psychometric properties. CyberPsychology \& Behavior, Vol. 12(1), pp. 16.

Munro, B. H. (2005). Statistical methods for health care research (Vol. 1). Lippincott Williams \& Wilkins.

Müller, K. W., Dreier, M., Beutel, M. E., Duven, E., Giralt, S. ve Wölfling, K. (2016). A hidden type of internet addiction? Intense and addictive use of social networking sites in adolescents, Computers in Human Behavior, Vol. 55, pp. 172-177.

Oberst, U., Wegmann, E., Stodt, B., Brand, M., \& Chamarro, A. (2017). Negative con- sequences from heavy social networking in adolescents: The mediating role of fear of missing out. Journal of Adolescence, 55, 51-60.

Odacı, H. ve Çelik, Ç. B. (2013). Who are problematic internet users? An investigation of the correlations between problematic internet use and shyness, loneliness, narcissism, aggression and self-perception. Computers in Human Behavior, Vol. 29(6), pp. 2382-2387. 
H. Ayhan Gökcek - A. E. Yurtsever - E. Y1ldız 13/3 (2021) 1985-2002

Oghuma, A. P., Libaque-Saenz, C. F., Wong, S. F. ve Chang, Y. (2016). An expectation confirmation model of continuance intention to use mobile instant messagin. Telematics Information, Vol. 33(1), pp. 34-47.

O'Guinn, T. C., \& Faber, R. J. (1989). Compulsive buying: A phenomenological exploration. Journal of Consumer Research, 16(2), 147-157.

Primack, B. A., Shensa, A., Escobar-Viera, C. G., Barrett, E. L., Sidani, J. E., Colditz, J. B. ve James, A. E. (2017). Use of multiple social media platforms and symptoms of depression and anxiety: A nationallyrepresentative study among U.S. young adults. Computers in Human Behavior, Vol. 69, pp. 1-9.

Przybylski, A. K., Murayama, K., Dehaan, C. R. ve Gladwell, V. (2013). Motivational, emotional, and behavioral correlates of fear of missing out. Computers in Human Behavior, Vol. 29(4), pp. 1841-1848.

Ravindran, T., Kuan, Y., Chua, A. ve Hoe Lian, D. G. (2014). Antecedents and effects of social network fatigue. Journal of the Association for Information Science and Technology, 65(11), pp. 2306-2320.

Riordan, B. C., Flett, J. A. M., Hunter, J. A., Scarf, D., \& Conner, T. S. (2015). Fear of Missing Out (FoMO): The relationship between FoMO, alcohol use, and alcohol-related consequences in college students. Annals of Neuroscience and Psychology, Vol. 2(7), pp. 1-7.

Rook, D. W., \& Fisher, R. J. (1995). Normative influences on impulsive buying behavior. Journal of consumer research, 22(3), 305-313.

Rook, D.W. (1987). The buying impulse. Journal of Consumer Research, Vol. 14, pp. 189-199.

Schreiber, J. B., Nora, A., Stage, F. K., Barlow, E. A., ve King, J. (2006). Reporting structural equation modeling and confirmatory factor analysis results: A review. The Journal of Educational Research, 99(6), 323-338.

Schumacker, R. E. ve Lomax R. G. (2010). A Beginner's Guide to Structural Equation Modeling. New York: Taylor \& Francis Group; p.85-90.

Sertbaş, G. ve Bahar, A. (2004). Anksiyete ve anksiyete ile baş etmede hemşirelik girişimleri. Hemşirelik Forumu Dergisi, Sayl. 5, ss. 39-44.

Sokol, L., Beck, A. T., Greenberg, R. L., Wright, F. D., ve Berchick, R. J. (1989). Cognitive therapy of panic disorder: A nonpharmacological alternative. Journal of Nervous and Mental Disease, Vol. 177(12), 711-716.

Sriwilai, K. ve Charoensukmongkol, P. (2016). Face it, don't Facebook it: Impacts of social media addiction on mindfulness, coping strategies and the consequence on emotional exhaustion. Stress $\mathcal{E}$ Health, Vol. 32(4), 427-434.

Stein, M. B. ve Sareen, J. (2015). Generalized anxiety disorder. The New England Journal of Medicine, Vol. 373(21), 2059-2068.

Stern, H. (1962). The significance of impulse buying today. Journal of Marketing, Vol. 26, 59-63.

Şimşek, Ö. F. (2007). Yapısal eşitlik modellemesine giriş:(temel ilkeler ve LISREL uygulamaları). Ekinoks.

Waltz, C. F., Strickland, O. L., \& Lenz, E. R. (Eds.). (2010). Measurement in nursing and health research. Springer publishing company.

Wang, J., \& Wang, X. (2019). Structural equation modeling: Applications using Mplus. John Wiley \& Sons.

Wolniewicz, C. A., Tiamiyu, M. F., Weeks, J. W. ve Elhai, J. D. (2018). Problematic smartphone use and relations with negative affect, fear of missing out, and fear of negative and positive evaluation. Psychiatry Research, Vol. 262, 618-623.

Xiao, H., Zhang, Z. \& Zhang, L. (2020). A diary study of impulsive buying during the COVID-19 pandemic, Current Psychology. 